\title{
Association between total, processed, red and white meat consumption and all-cause, CVD and IHD mortality: a meta-analysis of cohort studies
}

\author{
Itziar Abete $^{1,2 *}$, Dora Romaguera ${ }^{1,3}$, Ana Rita Vieira ${ }^{1}$, Adolfo Lopez de Munain ${ }^{2,4,5}$ and \\ Teresa Norat ${ }^{1}$ \\ ${ }^{1}$ Department of Epidemiology and Biostatistics, Faculty of Medicine, School of Public Health, Imperial College London, \\ St Mary's Campus, Norfolk Place, Paddington, London W2 1PG, UK \\ ${ }^{2}$ Department of Neuroscience, Institute Biodonostia, San Sebastián, Spain \\ ${ }^{3}$ CIBER Fisiopatologia de la Obesidad y Nutrición, Institute Carlos III, Ministry of Economy and Competitiveness, \\ Madrid, Spain \\ ${ }^{4}$ Department of Neurosciences, University of Basque Country (UPV-EHU), San Sebastián, Spain \\ ${ }^{5}$ CIBERNED, Centro de Investigaciones Biomedicas en Red sobre Enfermedades Neurodegenerativas, Institute Carlos III, \\ Ministry of Economy and Competitiveness, Madrid, Spain
}

(Submitted 6 December 2013 - Final revision received 24 April 2014-Accepted 28 April 2014 - First published online 16 June 2014)

\begin{abstract}
An association between processed and red meat consumption and total mortality has been reported by epidemiological studies; however, there are many controversial reports regarding the association between meat consumption and CVD and IHD mortality. The present metaanalysis was carried out to summarise the evidence from prospective cohort studies on the association between consumption of meat (total, red, white and processed) and all-cause, CVD and IHD mortality. Cohort studies were identified by searching the PubMed and ISI Web of Knowledge databases. Risk estimates for the highest $v$. the lowest consumption category and dose-response meta-analysis were calculated using a random-effects model. Heterogeneity among the studies was also evaluated. A total of thirteen cohort studies were identified (1674272 individuals). Subjects in the highest category of processed meat consumption had 22 and $18 \%$ higher risk of mortality from any cause and CVD, respectively. Red meat consumption was found to be associated with a 16\% higher risk of CVD mortality, while no association was found for total and white meat consumption. In the dose-response meta-analysis, an increase of $50 \mathrm{~g} / \mathrm{d}$ in processed meat intake was found to be positively associated with all-cause and CVD mortality, while an increase of $100 \mathrm{~g} / \mathrm{d}$ in red meat intake was found to be positively associated with CVD mortality. No significant associations were observed between consumption of any type of meat and IHD mortality. The results of the present meta-analysis indicate that processed meat consumption could increase the risk of mortality from any cause and CVD, while red meat consumption is positively but weakly associated with CVD mortality. These results should be interpreted with caution due to the high heterogeneity observed in most of the analyses as well as the possibility of residual confounding.
\end{abstract}

Key words: Meta-analyses: Mortality: Meat: Cohort studies

In the last 50 years, there has been a shift in the structure of the diet towards a higher-energy density one, characterised by higher intakes of fat and proteins (mostly from animal sources) and added sugars present in foods and lower intakes of complex carbohydrates, fruits and vegetables. At the same time, chronic diseases have become the main cause of CVD and cancer mortality, leading in the list of mortality causes in Western countries ${ }^{(1)}$. Thus, the knowledge about the effect that nutrients and foods might have on health is of great importance for public health management. The intake of meat, specifically red and processed, has increased in industrialised countries, resulting in it becoming the basic component of meals. The effect of meat consumption on health is being studied in depth by nutritional epidemiologists $^{(2-5)}$. General meat consumption has been reported to be associated with all-cause and specific-cause mortality. However, when considering the type of meat consumed, different associations have been observed. Systematic reviews and meta-analyses have found a higher incidence of CVD, diabetes and some types of cancers to be related to higher red

Abbreviation: RR, relative risk.

*Corresponding author: I. Abete, fax +207594 0768, email itziar.imperial@gmail.com 
and processed meat consumption ${ }^{(6-10)}$, while no association or a tendency towards an inverse association between white meat consumption and total mortality has been observed in some $\operatorname{cases}^{(11)}$. Large prospective studies have found a higher incidence of CVD and a higher risk of all-cause mortality among greater meat eaters ${ }^{(11-13)}$. Very recently, results obtained from another meta-analysis on red and processed meat consumption have shown that the consumption of processed meat and total red meat is positively associated with all-cause mortality ${ }^{(14)}$. However, there is considerable scientific debate regarding the association between meat consumption and CVD and IHD mortality ${ }^{(11-13,15-18)}$. Most of the positive associations found between meat consumption and CVD mortality have been observed in studies conducted in North America ${ }^{(1112)}$ and Europe ${ }^{(13,19)}$, while results obtained from Asian studies do not indicate a clear association ${ }^{(15,16)}$. As the evidence from prospective cohort studies on the association of white, red and processed meat consumption with allcause, CVD and IHD mortality has not been summarised yet, we carried out a meta-analysis to quantitatively summarise the existing published evidence from cohort studies on the association between the consumption of total meat and three types of meats (white, red and processed) and the risk of death from any cause, CVD and IHD.

\section{Methods}

\section{Search strategy}

We searched the PubMed and ISI Web of Knowledge databases to identify published prospective cohort studies in which dietary intake was measured at baseline (through August 2013). Keywords included, either in the title or in the abstract (without restrictions), the following: meat; red meat; white meat; processed meat; ham; sausages; hamburger; bacon; luncheon meats; beef; poultry; pork; rabbit; turkey; lamb; duck; all combined with mortality; total mortality; death; fatal coronary heart disease; fatal event and CVD; IHD; myocardial infarction; heart attack; heart failure. Death from CVD included mortality cases due to diseases of the circulatory system, IHD and cerebrovascular diseases. The reference lists of the selected studies and systematic reviews and meta-analyses were examined to identify further studies.

'Red meat' was defined as fresh meat from beef, veal, lamb, or pork, hamburgers and meatballs. In the study carried out by Sinha et al. ${ }^{(11)}$, red meat included processed and unprocessed meats; therefore; the analysis was repeated by excluding this study. 'White meat' was defined as poultry (chicken and turkey) and rabbit. In one study ${ }^{(11)}$, fish was combined with the white meat consumption group; thus, the analysis was repeated by excluding this study. 'Processed meat' was defined as any meat preserved by smoking, curing or salting or addition of chemical preservatives, such as bacon, salami, sausages, hot dogs or luncheon meats. 'Total meat' was defined as the total of these three categories.

We contacted the authors of four studies ${ }^{(13,15-17)}$ to obtain missing data needed to conduct dose-response analyses. Only two authors ${ }^{(15,17)}$ provided the requested information.

\section{Study selection}

We selected prospective cohort studies in which the relationship between the intake of total meat and/or red meat and/ or white meat and/or processed meat and total mortality and/or mortality from CVD and/or mortality from IHD was investigated. Studies comparing only vegetarians and non-vegetarians ${ }^{(20-22)}$ were excluded, but three studies that reported the comparison of vegetarians and non-vegetarians also analysed dietary variables (including meat) regardless of the group (vegetarian and non-vegetarian) and were therefore included in the analysis ${ }^{(19,23,24)}$.

Risk ratios had to be available with 95\% CI either in the publication or on being requested from the authors. To be included in the dose-response analysis, a quantitative measure of intake had to be presented in the article or be obtainable from the authors. When several publications of the same study were identified, only the most recent or most detailed publication was used. The Shanghai Women's Health Study was included in two articles ${ }^{(16,18)}$; therefore, for the comparison of the highest $v$. the lowest consumption category, only the study carried out by Lee et $a l .{ }^{(16)}$ was considered, and for the dose-response meta-analysis, only the study carried out by Takata et al. ${ }^{(18)}$ was considered.

\section{Data extraction}

The following information was extracted from each article: country; sample size and number of total, CVD or IHD deaths; method used for the identification and verification of the cause of death; duration of follow-up; method used for dietary intake assessment (FFQ, or diet history, only at baseline or updated during follow-up and whether the method had been validated); meat type; highest and lowest intake amounts; relative risks (RR) and 95\% CI; variables included in the adjusted model (Table 1). The articles were independently reviewed by two researchers (A. R. V. and I. A. G.) and information was extracted.

\section{Statistical analyses}

We conducted two types of meta-analyses. First, we combined the RR for the highest $v$. the lowest category of meat (red, white, processed and total) consumption using a randomeffects model, which considers both within-study and between-study variations ${ }^{(25)}$. Second, we conducted a doseresponse meta-analysis using the methods proposed by Greenland \& Longnecker ${ }^{(26)}$ and Orsini et al. ${ }^{(27)}$ to derive the log-linear dose-response slope within each study from categorical data. The method requires that the distribution of cases and person-years and the RR with the variance estimates be given for at least three quantitative exposure categories. The reported median or mean level of meat intake in each category of consumption was assigned to the corresponding RR for each study. For studies that reported intake by ranges ${ }^{(17,28)}$, we estimated the mid-point in each category by calculating the average of the lower and upper bounds. When the highest or lowest category of consumption was 


\section{N British Journal of Nutrition}

Table 1. Characteristics of the selected prospective cohort studies on the association between meat (total, white, red and processed) consumption and mortality (all-cause, CVD or IHD) (Hazard ratios (HR) and $95 \%$ confidence intervals and number of participants)

\begin{tabular}{|c|c|c|c|c|c|c|c|c|}
\hline $\begin{array}{l}\text { Author, publication } \\
\text { year, location, } \\
\text { cohort name }\end{array}$ & Participants & $\begin{array}{l}\text { Dietary intake } \\
\text { assessment method }\end{array}$ & Total/CVD/IHD death cases & Exposure & Highest $v$. lowest intake & Outcome & $\begin{array}{l}\text { HR for the highest } \\
v \text {. the lowest category }\end{array}$ & Adjustment variables \\
\hline $\begin{array}{l}\text { Mann"(24), 1997, UK, } \\
\text { Vegetarianand non- } \\
\text { vegetarian Society of } \\
\text { the UK }\end{array}$ & $\begin{array}{l}n 10802 \text { (M 4102, F 6700) } \\
\text { Age } 16-79 \text { years } \\
\text { Follow-up 13.3 years }\end{array}$ & $\begin{array}{l}\text { Semi-quantitative FFQ } \\
\text { At baseline } \\
\text { Validated for dietary } \\
\text { fibre intake }\end{array}$ & $\begin{array}{l}\text { Total//HD: 392/64 } \\
\text { Case ascertainment: } \\
\text { death certificates }\end{array}$ & TM & $\begin{array}{l}\text { Predefined categories } \\
\text { Daily } v .0\end{array}$ & IHD mortality & $1.18(95 \% \mathrm{Cl} 0.64,2.18)$ & $\begin{array}{l}\text { Age, sex, smoking status } \\
\text { and social class }\end{array}$ \\
\hline $\begin{array}{l}\text { Fraser(23), 1999, } \\
\text { California, Seventh-day } \\
\text { Adventist Study }\end{array}$ & $\begin{array}{l}n 34198 \text { (M 13857, F 20 341) } \\
\text { Age } 25-\geq 85 \text { years } \\
\text { Follow-up } 6 \text { years }\end{array}$ & $\begin{array}{l}\text { FFQ } \\
\text { Fifty-one different foods } \\
\text { At baseline }\end{array}$ & $\begin{array}{l}\text { Total: } 2716 \\
\text { Case ascertainment: linkage } \\
\text { with state death certificate } \\
\text { files and individual follow-up }\end{array}$ & RM & $\begin{array}{l}\text { Predefined categories } \\
\geq 3 \text { times/week } v .0\end{array}$ & IHD mortality & $\begin{array}{l}\text { Men 2.31 (95\% Cl 1.11, 4.78) } \\
\text { Women 0.76 (95\% Cl 0.37, 1.56) }\end{array}$ & $\begin{array}{l}\text { Age, smoking status, PA, } \\
\text { BMI, HBP, and bread, } \\
\text { nut, fish, cheese, } \\
\text { coffee, legume, } \\
\text { and fruit consumption }\end{array}$ \\
\hline $\begin{array}{l}\text { Whitemana(28), } 1999, \\
\text { Bedfordshire UK, } \\
\text { OXCHECK Study }\end{array}$ & $\begin{array}{l}\text { n } 10522 \text { (M 4929, F 5593) } \\
\text { Age } 35-64 \text { years } \\
\text { Follow-up } 9 \text { years }\end{array}$ & $\begin{array}{l}\text { Simple FFQ } \\
\text { At baseline }\end{array}$ & $\begin{array}{l}\text { Total//HD: } 514 / 107 \\
\text { Case ascertainment: } \\
\text { death certificates }\end{array}$ & $\begin{array}{l}\mathrm{RM} \\
\mathrm{WM} \\
\mathrm{PM}^{*}\end{array}$ & $\begin{array}{l}\text { Predefined categories } \\
4-7 v .<1 d / \text { week }\end{array}$ & IHD mortality & $\begin{array}{l}\text { RM } 0.57(95 \% \mathrm{Cl} 0.30,1.07) \\
\text { WM } 0.95(95 \% \mathrm{Cl} 0.38,2.38) \\
\text { PM } 1.28(95 \% \mathrm{Cl} 0.46,3.54)\end{array}$ & $\begin{array}{l}\text { Sex, smoking status and } \\
\text { age grouu, AC, } \\
\text { social class, and intake } \\
\text { of fruits, vegetables, } \\
\text { puddings, cakes, } \\
\text { biscuits and sweets }\end{array}$ \\
\hline $\begin{array}{l}\text { Fortes(29), 2000, Italy, } \\
\text { Elderly cohort study }\end{array}$ & $\begin{array}{l}n 161 \text { (M } 52, \text { F 109) } \\
\text { Age } \geq 65 \text { years } \\
\text { Follow-up } 5 \text { years }\end{array}$ & $\begin{array}{l}\text { Semi-quantitative FFQ } \\
114 \text { items at baseline } \\
\text { Validated }\end{array}$ & $\begin{array}{l}\text { Total: } 53 \\
\text { Case ascertainment: } \\
\text { examining the Registry } \\
\text { Office of the Municipality } \\
\text { of Rome }\end{array}$ & TM & $\begin{array}{l}\text { Predefined categories } \\
>1 \mathrm{v} .<1 \text { time/month }\end{array}$ & $\begin{array}{l}\text { All-cause } \\
\text { mortality }\end{array}$ & $1.82(95 \% \mathrm{Cl} 0.91,3.60)$ & $\begin{array}{l}\text { Sex, age, EL, BMI, } \\
\text { smoking status, } \\
\text { cognitive function } \\
\text { and chronic diseases }\end{array}$ \\
\hline $\begin{array}{l}\text { Jamroziki(30), 2000, } \\
\text { Western Australia, } \\
\text { The Perth Community } \\
\text { Stroke Study }\end{array}$ & $\begin{array}{l}n 817 \text { (M 392, F 425) } \\
\text { Mean age } \geq 75 \text { years } \\
\text { Follow-up } 5 \text { years }\end{array}$ & $\begin{array}{l}\text { Personal interviews } \\
\text { At baseline }\end{array}$ & $\begin{array}{l}\text { Total/CVD: 198/96 } \\
\text { Case ascertainment: linkage } \\
\text { to name-identified unit } \\
\text { mortality and to the } \\
\text { Hospital Morbidity data system }\end{array}$ & TM & $\begin{array}{l}\text { Predefined categories } \\
>4 \mathrm{v} . \leq 4 \text { times/week }\end{array}$ & CVD mortality & $0.62(95 \% \mathrm{Cl} 0.39,0.97)$ & $\begin{array}{l}\text { Sex, age, Barthel score, } \\
\text { Frenchay score, } \\
\text { Rankin score, history } \\
\text { of MI, TIA or stroke, } \\
\text { DM, AC and smoking } \\
\text { status }\end{array}$ \\
\hline $\begin{array}{l}\text { Chang-Claude(19), } \\
\text { 2005, Germany, } \\
\text { The German } \\
\text { vegetarian study }\end{array}$ & $\begin{array}{l}n 1904(\mathrm{M} 858, \mathrm{~F} 1046) \\
\text { Age } 34-\geq 75 \text { years } \\
\text { Follow-up } 21 \text { years }\end{array}$ & $\begin{array}{l}\text { Semi-quantitative FFQ } \\
\text { Updated at } 5 \text { and } \\
11 \text { years after baseline }\end{array}$ & $\begin{array}{l}\text { Total/CVDD/HD: } 535 / 255 / 72 \\
\text { Total/CVDDIHD: } 243 / 1117 / 43 \text { men } \\
\text { Total/CVD/IHD: 292/138/29 women } \\
\text { Case ascertainment: Registrar's } \\
\text { Office information; death certificates }\end{array}$ & $\begin{array}{l}\mathrm{TM} \\
\mathrm{PM}\end{array}$ & $\begin{array}{l}\text { Predefined categories } \\
T M \geq 3 \text { times/week v. } 0 \\
\text { PM }>1 \text { /month v. } 0\end{array}$ & CVD mortality & $\begin{array}{l}\text { TM } 2.02(95 \% \mathrm{Cl} 0.91,4.44) \\
\text { PM 2.38 }(95 \% \mathrm{Cl} 0.94,6.05)\end{array}$ & $\begin{array}{l}\text { Age, sex, BMI, smoking } \\
\text { status, PA, AC and EL }\end{array}$ \\
\hline $\begin{array}{l}\text { Sinha } a^{(11)}, 2009 \text {, six US } \\
\text { states, } \\
\text { NIH-AARP Diet and } \\
\text { Health } \\
\text { Study Cohort }\end{array}$ & $\begin{array}{l}n 545653(\mathrm{M} 322263 \\
\mathrm{F} 223390) \\
\text { Age } 50-71 \text { years }\end{array}$ & $\begin{array}{l}\text { 124-item FFQ } \\
\text { At baseline }\end{array}$ & $\begin{array}{l}\text { Case ascertainment: linkage } \\
\text { to the Social Security } \\
\text { Administration; Death } \\
\text { Master File; searching } \\
\text { the National Death Index }\end{array}$ & $\begin{array}{l}\text { RM† } \\
\text { WM } \ddagger\end{array}$ & 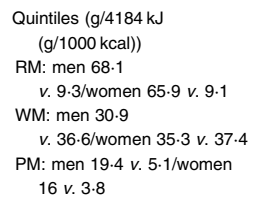 & CVD mortality & $\begin{array}{r}\text { RM: men } 1.27(95 \% \mathrm{Cl} 1.20,1.35) \\
\text { women } 1.50(95 \% \mathrm{Cl} 1.37,1.65) \\
\text { WM: } \operatorname{men} 1.05(95 \% \mathrm{Cl} 1.00,11.11) ; \\
\text { women } 1.04(95 \% \mathrm{Cl} 0.96,1.14) \\
\text { PM: } \operatorname{men} 1.09(95 \% \mathrm{Cl} 1.03,1.15) ; \\
\text { women } 1.38(95 \% \mathrm{Cl} 1.26,1.51)\end{array}$ & $\begin{array}{l}\text { Age, race, TEI, EL, marital } \\
\text { status, family history of } \\
\text { cancer, BMM, smoking } \\
\text { history, smoking status, } \\
\text { PA, AC, vitamin } \\
\text { supplement use, } \\
\text { and fruit and vegetable } \\
\text { intake }\end{array}$ \\
\hline $\begin{array}{l}\text { Nagaa(15), 2012, Japan, } \\
\text { JACC Study }\end{array}$ & $\begin{array}{l}\text { n } 51683 \text { ( M } 20466, F 31217 \text { ) } \\
\text { Age } 40-79 \text { years } \\
\text { Follow-up } 18.4 \text { years }\end{array}$ & $\begin{array}{l}\text { FFQ } \\
\text { Thirty-three foods and } \\
\text { five meat items } \\
\text { At baseline } \\
\text { Validated }\end{array}$ & $\begin{array}{l}\text { CVD/IHD: 2685/537 } \\
\text { CVD/HD: 1317/301 men } \\
\text { CVD/IHD: 1368/236 women } \\
\text { Case ascertainment: review } \\
\text { of death certificates }\end{array}$ & $\begin{array}{l}\text { TM } \\
\text { RM } \\
\text { WM } \\
\text { PM }\end{array}$ & 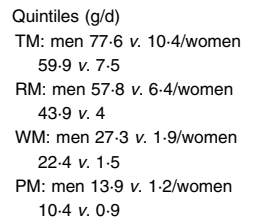 & CVD mortality & $\begin{array}{l}\text { TM: men } 1.00 \text { (95\% Cl 0.84, } \\
\text { 1.20); women } 1.07(95 \% \\
\text { Cl } 0.90,1.28)\end{array}$ & $\begin{array}{l}\text { Age, BMI, AC, mental } \\
\text { stress, waking time, } \\
\text { PA, EL, HBP, DM, TEI } \\
\text { and energy-adjusted } \\
\text { food intake (rice, soya, } \\
\text { fish, vegetables and } \\
\text { fruits) }\end{array}$ \\
\hline $\begin{array}{l}\text { Pa(12), 2012, US, } \\
\text { HPFS and NHS }\end{array}$ & $\begin{array}{l}n 121342 \text { (M } 37698, \text { F 83644) } \\
\text { Age } 30-75 \text { years } \\
\text { Follow-up HPFS } 22 \text { years, } \\
\text { NHS } 28 \text { years }\end{array}$ & $\begin{array}{l}\text { Sixty-one-item FFQ } \\
\text { expanded to } 131 \text { to } \\
\quad 161 \text { items } \\
\text { Updated every } 4 \text { years } \\
\text { Validated }\end{array}$ & $\begin{array}{l}\text { Total/CVD: 8926/2716 men } \\
\text { Total/CVD: 15000/3194 women } \\
\text { Case ascertainment: next-of-kin } \\
\text { reports; searching the } \\
\text { National Death Index; } \\
\text { death certificates }\end{array}$ & $\begin{array}{l}\text { RM } \\
\text { PM }\end{array}$ & $\begin{array}{l}\text { TM: men } 2.36 \text { v. } 0.22 / \text { women } \\
3.10 v .0 .53 \\
\text { RM: men } 1.46 v .0 .17 / \text { women } \\
1.64 \text { v. } 0.37 \\
\text { PM: men } 0.74 \text { v. } 0.02 / \text { women } \\
0.64 \text { v. } 0.05\end{array}$ & CVD mortality & $\begin{array}{l}\text { TM: men 1.35 (95\% Cl 1.19, } \\
\text { 1.53); women 1.45 (95\% Cl 1.30, } \\
\text { 1.63) } \\
\text { RM: men 1.32 (95\% Cl 1.16, 1.49); } \\
\quad \text { women 1.39 (95\% Cl 1.24, 1.55) } \\
\text { PM: men 1.25 (95\% Cl 1.11. 1.41); } \\
\text { women 1.29 (95\% Cl 1.15, 1.43) }\end{array}$ & $\begin{array}{l}\text { Age, BMI, race, smoking } \\
\text { status, AC, PA, vitamin } \\
\text { supplement use, } \\
\text { aspirin use, family } \\
\text { history of DM, MI or } \\
\text { cancer and baseline } \\
\text { history of DM, HBP or } \\
\text { hypercholesterolaemia, } \\
\text { and HRT, TEl, whole } \\
\text { grain intake, and } \\
\text { fruit and vegetable } \\
\text { intake }\end{array}$ \\
\hline
\end{tabular}




\begin{tabular}{|c|c|c|c|c|c|c|c|c|}
\hline $\begin{array}{l}\text { Author, publication } \\
\text { year, location, } \\
\text { cohort name }\end{array}$ & Participants & $\begin{array}{l}\text { Dietary intake } \\
\text { assessment method }\end{array}$ & Total/CVD/HD death cases & Exposure & Highest $v$. lowest intake & Outcome & $\begin{array}{l}\text { HR for the highest } \\
v \text {. the lowest category }\end{array}$ & Adjustment variables \\
\hline \multirow[t]{3}{*}{$\begin{array}{l}\text { Kappelerer(17), 2013, US, } \\
\text { NHANES III }\end{array}$} & $n 17611$ (M 8239, F 9372) & Eighty-one-item FFQ & Total/CVD: 3683/1554 & RM & Predefined categories & CVD mortality & $\begin{array}{l}\text { RM: men } 0.76(95 \% \text { Cl 0.26, 2.23); } \\
\text { women } \\
3.50 \text { (95\% Cl 1 1.35, 9.05) }\end{array}$ & \multirow{5}{*}{$\begin{array}{l}\text { Age, race, sex, smoking } \\
\text { status, AC, PA, SCE, } \\
\text { BMI, marital status, } \\
\text { fruit and vegetable } \\
\text { intake, history } \\
\text { of HBP, DM, } \\
\text { hypercholesterolaemia, } \\
\text { aspirin use, } \\
\text { ibuprofen use, vitamin } \\
\text { supplement use, family } \\
\text { history of DM or } \\
\text { hypercholesterolaemia, } \\
\text { HRT and oral } \\
\text { contraceptive use } \\
\text { BW, height, TEI, AC, PA, } \\
\text { EL,, smoking status, } \\
\text { and duration of } \\
\text { smoking. Types of } \\
\text { meats were mutually } \\
\text { adjusted for each } \\
\text { other. Models were } \\
\text { stratified by age, centre } \\
\text { and sex }\end{array}$} \\
\hline & Age $33-45$ years & Potion size not assessed & $\begin{array}{l}\text { Case ascertainment: a process } \\
\text { of probabilistic matching and } \\
\text { death certificate review }\end{array}$ & WM & $\mathrm{RM} \geq 45 \mathrm{v} .0-6$ times/month & & $\begin{array}{l}\text { PM: men } 0.74(95 \% \mathrm{Cl} 0.41,1.33) \text {; } \\
\quad \text { women } \\
1.01(95 \% \mathrm{Cl} 0.67,1.52)\end{array}$ & \\
\hline & Follow-up 22 years & At baseline & & PM & $\begin{array}{l}\text { WM } \geq 13 \mathrm{v} .0 \text { times } / \text { month } \\
\mathrm{PM} \geq 30 \mathrm{v} .0 \text { times/month }\end{array}$ & & $\begin{array}{l}\text { WM: men } 0.94(95 \% \mathrm{Cl} 0.51,1.73) \text {; } \\
\text { women } \\
1.23(95 \% \mathrm{Cl} 0.66,2.29)\end{array}$ & \\
\hline \multirow{2}{*}{$\begin{array}{l}\text { Rohrmann(11), 2013, } \\
10 \text { European } \\
\text { countries, EPIC } \\
\text { Study }\end{array}$} & $n 448568$ & $\begin{array}{l}\text { Country-specific instruments, } \\
300-350 \text {-item FFQ } \\
+7 \text { d food record }\end{array}$ & Total/CVD: 26 344/5556 & RM & Predefined categories & \multirow[t]{2}{*}{ CVD mortality } & RM $1.07(95 \% \mathrm{Cl} 0.82,1.40)$ & \\
\hline & $\begin{array}{l}\text { Age } 35-69 \text { years } \\
\text { Follow-up } 17.8 \text { years }\end{array}$ & $\begin{array}{l}7 \mathrm{~d} \text { menu book }+ \text { interview } \\
\text { At baseline } \\
\text { Validated by each centre }\end{array}$ & $\begin{array}{l}\text { Case ascertainment: record } \\
\text { linkages with health registries, } \\
\text { death indices or active follow-up; } \\
\text { verification of cases }\end{array}$ & $\begin{array}{l}\text { PM } \\
\text { WM }\end{array}$ & $\begin{array}{l}\mathrm{RM} \\
\mathrm{PM} \geq 160 \mathrm{~g} / \mathrm{d} v \mathrm{v} .0 \\
\mathrm{WM} \geq 80 \mathrm{~g} / \mathrm{d} v .0\end{array}$ & & $\begin{array}{l}\text { PM } 1.72(95 \% \mathrm{Cl} 1.29,2.30) \\
\text { WM } 0.94(95 \% \mathrm{Cl} 0.73,1 \cdot 21)\end{array}$ & \\
\hline \multirow[t]{3}{*}{$\begin{array}{l}\text { Takatat }{ }^{(18)}, 2013, \text { China, } \\
\text { SWHS and SMHS }\end{array}$} & $n 134290$ (M 61 128, F 73 162) & $\mathrm{FFQ}$ at baseline & Total/CVD/HD: 2733/875/284 men & RM & Quintiles (g/d) & \multirow[t]{3}{*}{ CVD mortality } & $\begin{array}{l}\text { RM: men } 1.15(95 \% \mathrm{Cl} 0.90,1 \cdot 48) \text {; } \\
\text { women } \\
\text { 0.89 (95\% Cl } 0.72,1.09) \text {; both } \\
0.99(95 \% \mathrm{Cl} 0.84,1.16)\end{array}$ & \multirow{3}{*}{$\begin{array}{l}\text { Age at baseline, TEL, } \\
\text { income occupation, EL, } \\
\text { co-morbidity index, PA, } \\
\text { total vegetable, total } \\
\text { fruit, fish, and RM } \\
\text { or WM intake, smoking } \\
\text { history and AC (only } \\
\text { in men) }\end{array}$} \\
\hline & Age $40-74$ years & Validated & Total/CVD/IHD: 4210/1288/306 women & wM & $\begin{array}{l}\text { RM: men } 126 \text { v. 21.4/women } \\
103.4 \text { v. } 16.5\end{array}$ & & $\begin{array}{l}\text { WM: men } 0.81 \text { (95\% Cl 0.65, 1.02); } \\
\text { women }\end{array}$ & \\
\hline & $\begin{array}{l}\text { Follow-up SMHS 5.5 years, } \\
\text { SWHS 11.2 years }\end{array}$ & & $\begin{array}{l}\text { Case ascertainment: linkages to Vital } \\
\text { Statistics Registry; in-person visits } \\
\text { to participants' homes; death } \\
\text { certificates }\end{array}$ & & $\begin{array}{l}\text { WM: men } 22.3 \mathrm{v} .11 \cdot 9 / \text { women } \\
19.9 \text { v. } 11 \cdot 9\end{array}$ & & $\begin{array}{l}1.03(95 \% \text { Cl 0.84, } 1.26) \text {; both } \\
0.93(95 \% \text { Cl } 0.79,1.08)\end{array}$ & \\
\hline \multirow{3}{*}{$\begin{array}{l}\text { Lee(16), 2013, Bangladesh, } \\
\text { China, Japan, Korea } \\
\text { and Taiwan, } \\
\text { eight Asian cohorts }\end{array}$} & $n 296721$ (M 112310, F 184411) & $\mathrm{FFQ}$ at baseline & Total/CVD: $24283 / 6373$ & TM & Quartiles (g/d) & \multirow[t]{3}{*}{ CVD mortality } & $\begin{array}{l}\text { TM: men } 0.91 \text { (95\% \% Cl } 0.78, \\
\text { 1.05); women } 1.02 \text { (95\% Cl } 0.89 \text {, } \\
\text { 1.18) }\end{array}$ & \multirow{3}{*}{$\begin{array}{l}\text { Age, BMI, education, } \\
\text { smoking habit, rural/ } \\
\text { urban residence, } \\
\text { alcohol intake, fruit } \\
\text { and vegetable } \\
\text { intake, and TEl }\end{array}$} \\
\hline & Age $18-92$ years & Validated by each centre & $\begin{array}{l}\text { Case ascertainment: linkage to death } \\
\text { registries or active follow-up }\end{array}$ & RM & $\begin{array}{l}\text { RM: men 14.2-92.3/women } \\
\text { 9.9-50.9 }\end{array}$ & & $\begin{array}{l}\text { RM: men } 0.87(95 \% \mathrm{Cl} 0.78,0.98) \\
\quad \text { women } 1.03(95 \% \mathrm{Cl} 0.85,1.25)\end{array}$ & \\
\hline & Follow-up 6.6-15.6 years & $\begin{array}{l}\text { Six to seventeen items } \\
\text { for meat } \\
\text { Portions or serving sizes were } \\
\text { assessed }\end{array}$ & & wM & $\begin{array}{l}\text { WM: men 4.6-22.3/women } \\
2 \cdot 8-15 \cdot 4\end{array}$ & & $\begin{array}{l}\text { WM: men } 0.82(95 \% \mathrm{Cl} 0.64,1.06) \text {; } \\
\text { women } \\
1.05(95 \% \mathrm{Cl} 0.92,1.18)\end{array}$ & \\
\hline
\end{tabular}

M, male; F, female; TM, total meat; RM, red meat; PA, physical activity; HBP, hypertension; WM, white meat; AC, alcohol consumption; PM, processed meat; EL, education level; MI, myocardial infarction; TIA, transient ischaemic attack; DM, diabetes mellitus; NIH-AARP, National Institutes of Health-American Association of Retired Persons; TEl, total energy intake; JACC, Japan Collaborative Cohort; HPFS, Health Professional Follow-up Study; NHS,
Nurses' Health Study; HRT, hormone-replacement therapy; NHANES III, Third National Health and Nutrition Examination Survey; SCE, socio-economic status; EPIC, European Prospective Investigation into Cancer and Nutrition; BW, body weight; SWHS, Shanghai Women's Health Study; SMHS, Shanghai Men's Health Study.

* Hamburgers are included in this group.

†This red meat group includes processed and unprocessed red meats.

† The white meat group includes fish consumption. 
open-ended, the open-ended interval length was assumed to be of the same length as the adjacent interval. When studies reported the intake in servings and time/d per week or $\mathrm{g} / 4184 \mathrm{~kJ}(\mathrm{~g} / 1000 \mathrm{kcal})^{(11,12,17,19,23,24,29,30)}$, we converted the intakes to grams of intake per $\mathrm{d}$ using standard units of $120 \mathrm{~g}$ for total, red and white meats and $50 \mathrm{~g}$ for processed meat $^{(31)}$. The results are presented per $100 \mathrm{~g} / \mathrm{d}$ for total, red and white meats and per $50 \mathrm{~g} / \mathrm{d}$ for processed meat. For studies that reported results stratified by sex but not results for men and women together, a combined estimate of the association was calculated using fixed-effects models before including the studies in the overall analysis. Overall risk estimates were calculated for men and women separately and combined.

Statistical heterogeneity among the studies was assessed using $I^{2}$, which is the amount of total variation that is explained by the between-study variation, and the $Q$ test $^{(32)}$, and values of $25,50,75$ and $>75 \%$ were considered to indicate low, moderate, high and very high heterogeneity, respectively. We conducted subgroup analyses by duration of follow-up ( $<20$ years or $\geq 20$ years), number of cases $(<5000$ or $\geq 5000)$, dietary intake assessment, consumption categories (predefined or quintiles) and differences in adjustment variables. We assessed publication bias using Egger's test $^{(33)}$ and Begg's test ${ }^{(34)}$; the results were considered to indicate publication bias when $P<0 \cdot 10^{(6)}$. To ensure that the results obtained were not simply due to the inclusion of one large study or a study with an extreme result, we carried out sensitivity analyses by excluding one study at a time to determine whether the results were robust. All statistical analyses were conducted using Stata, version 12, software (StataCorp). A two-tailed $P<0.05$ was considered statistically significant.

\section{Results}

\section{Study selection}

A total of thirteen cohort studies including 1674272 individuals, 163524 cases of total mortality, 44340 cases of CVD mortality and 1370 cases of IHD mortality were identified (Fig. 1). The characteristics of the thirteen studies are summarised in Table 1. Of these studies, five were carried out in Europe, four in the USA, one in Australia and three in Asia.

In the analysis of all-cause mortality, ten cohort studies could be included: five for total meat ${ }^{(12,16,24,29,30)}$ consumption; seven for red meat ${ }^{(11-13,16-18,28)}$ consumption; six for white meat ${ }^{(11,13,16-18,28)}$ consumption; five for processed meat ${ }^{(11-13,17,28)}$ consumption.

In the analysis of CVD mortality, nine cohort studies could be included: five for total meat ${ }^{(12,15,16,19,30)}$ consumption; seven for red meat ${ }^{(11-13,15-18)}$ consumption; six for white meat ${ }^{(11,13,15-18)}$ consumption; six for processed meat ${ }^{(11-13,15,17,19)}$ consumption.

In the analysis of IHD mortality, six cohort studies could be included: three for total meat ${ }^{(15,19,24)}$ consumption; four for red meat ${ }^{(15,18,23,28)}$ consumption; three for white meat ${ }^{(15,18,28)}$ consumption; three for processed meat ${ }^{(15,19,28)}$ consumption.
All-cause mortality. In the meta-analysis combining the risk estimates for the highest $v$. the lowest consumption category, the consumption of processed meat but not of total, red and white meats was found to be positively associated with all-cause mortality (RR 1.22; 95\% CI 1.16, 1.29; $I^{2}=44.4, P=0 \cdot 126$ ) (Figs. 2(a) and 3(a); Table 2). There was very high and significant heterogeneity among the studies, with the $I^{2}$ ranging from 86.9 to $95.4 \%$. In sensitivity analyses, the heterogeneity was substantially decreased for total meat consumption when the studies carried out by Lee et $a l^{(16)}$ and Jamrozik et $a l^{(30)}$ were excluded $\left(I^{2}=55.8 \%\right.$, $P=0 \cdot 104)$; thus, the RR increased and the CI moved to the right with a trend towards a positive association with all-cause mortality (RR 1.23; $95 \%$ CI 0.98, 1.53). For red meat consumption, the heterogeneity remained when each study was excluded one by one, and a positive association was confirmed (RR 1.14; 95\% CI 1.01, 1.29) when an Asian study $^{(16)}$ was excluded. For white meat consumption, between-study heterogeneity decreased $\left(I^{2}=0 \%, P=0.630\right)$ when a large American study ${ }^{(11)}$ was excluded, but no association with all-cause mortality was observed (RR 0.92; $95 \%$ CI $0 \cdot 84,1 \cdot 05)$.

The analysis stratified by sex showed that processed meat consumption was positively associated with an increased risk of all-cause mortality in both men (RR 1.22; 95\% CI $\left.1 \cdot 13,1 \cdot 31 ; I^{2}=60 \cdot 9, P=0.053\right)$ and women (RR $1.23 ; 95 \%$ CI $\left.1.19,1 \cdot 27 ; I^{2}=0, P=0 \cdot 670\right)$. Red meat consumption was associated with a $17 \%$ higher risk of all-cause mortality in men (RR 1.17; $95 \%$ CI 1.04, 1.32; $I^{2}=89.3, P<0.001$ ), but not in women (RR $1.13 ; 95 \%$ CI $0.96,1 \cdot 34 ; I^{2}=94 \cdot 1$, $P<0.001)$. White meat consumption was associated with a $5 \%$ lower risk of all-cause mortality only in women (RR 0.95; $95 \%$ CI $0.91,0.99 ; I^{2}=0, P=0 \cdot 805$ ).

Among the selected studies, two studies could not be included in the dose-response meta-analysis because the number of deaths and subjects for the consumption categories of each type of meat were not reported ${ }^{(16)}$ and meat consumption was divided into two categories ${ }^{(30)}$. The dose-response analysis showed that the RR for a $50 \mathrm{~g} / \mathrm{d}$ increase in processed meat intake was 1.25 (95\% CI $1.07,1.45 ; I^{2}=95.7 \%$, $P<0.001)$. In the analysis stratified by sex, the positive association was confirmed in both men and women. On the other hand, a $100 \mathrm{~g} / \mathrm{d}$ increase in total, red and white meat intake was not associated with all-cause mortality (Table 2). However, when the analysis was stratified by sex, a positive association was found between red meat consumption and mortality risk in both men (RR $1.21 ; 95 \%$ CI $1.15,1.26$; $\left.I^{2}=47 \cdot 7 \%, P=0 \cdot 137\right)$ and women (RR 1.14; $95 \%$ CI 1.00 , $\left.1 \cdot 30 ; I^{2}=91.4 \%, P<0 \cdot 001\right)$. There was no evidence of publication bias $(P>0 \cdot 10)$ in any of the analyses.

CVD mortality. Risk estimates for the comparison of the highest $v$. the lowest consumption category of processed meat (RR 1.18; 95\% CI 1.05, 1.32; $I^{2}=73.5, P=0.002$ ) and red meat (RR 1.16; $95 \%$ CI $1.03,1.32 ; I^{2}=82.5, P<0.001$ ) showed positive associations with CVD mortality. There was very high and significant heterogeneity in both cases (Figs. 2(b) and 3(b)). In the analysis of processed meat consumption, the heterogeneity ranged from $I^{2}=68.5 \%$ 


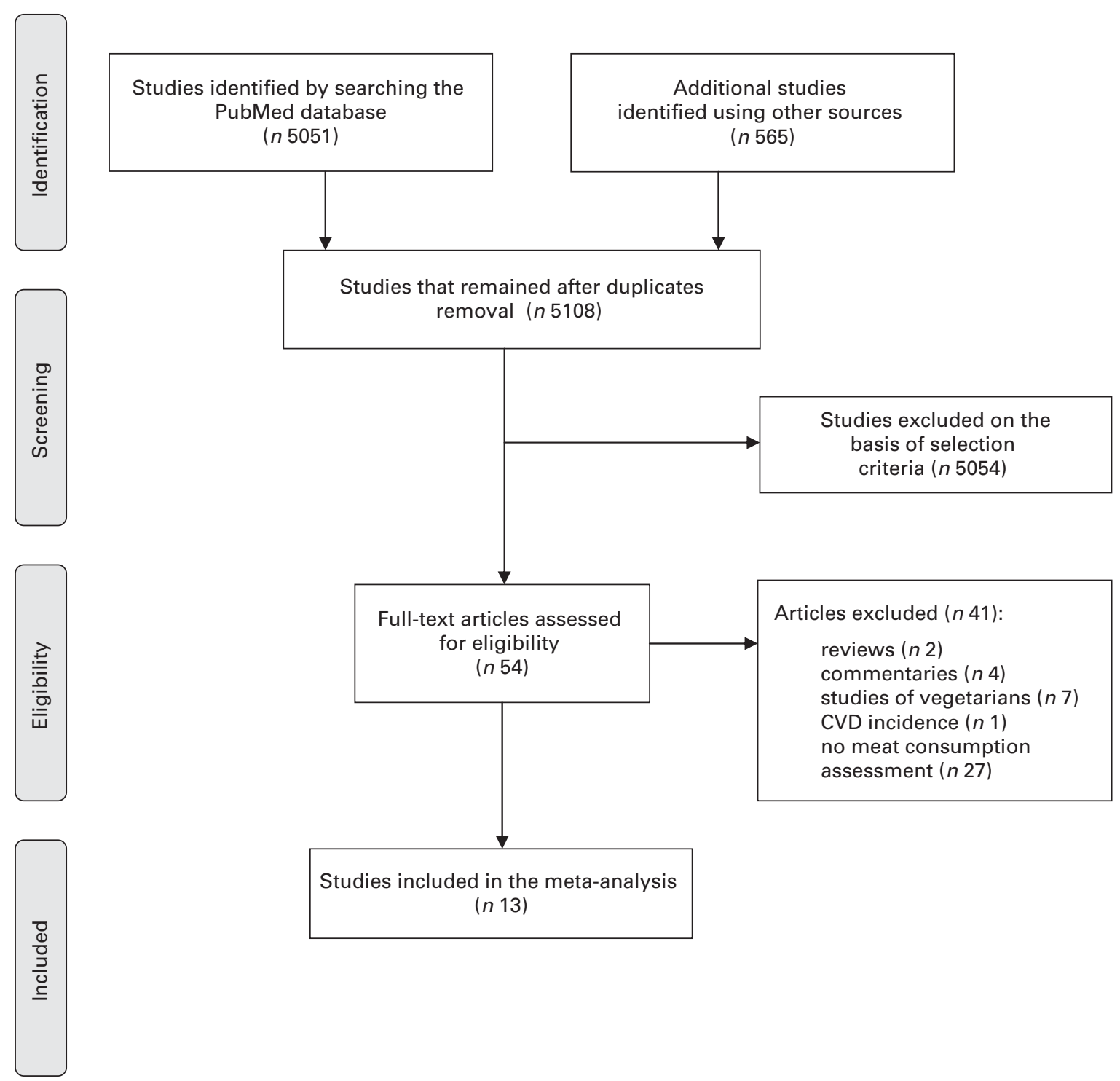

Fig. 1. PRISMA (Preferred Reporting Items for Systematic Reviews and Meta-Analyses) flowchart ${ }^{(40)}$. Screening and selection of studies analysing the association between meat (red/white/processed) consumption and CVD mortality. For more information, visit http://www.prisma-statement.org

$(P=0.013$ and a RR of $1.23(95 \%$ CI $1.09,1 \cdot 38))$ when a Japanese study ${ }^{(15)}$ was excluded to $I^{2}=89 \cdot 4 \%(P<0 \cdot 001$ and a RR of $1.20(95 \%$ CI $1.07,1.35))$ when a US study ${ }^{(17)}$ was excluded. In the sensitivity analysis of red meat consumption, the heterogeneity decreased substantially $\left(I^{2}=14.7 \%\right.$, $P=0$ 319) when Asian studies ${ }^{(15,16,18)}$ were excluded and the association was strengthened (RR 1.33; $95 \%$ CI 1.26, 1.40). When the analysis was stratified by sex, the association between processed and red meat consumption and CVD mortality was slightly strengthened in women but not in men (Table 2 ).

Total meat (RR 1.08; $95 \%$ CI 0.85, 1.36; $I^{2}=90 \cdot 6, P<0 \cdot 001$ ) and white meat (RR 1.01; 95\% CI 0.96, 1.07; $I^{2}=10.6$, $P=0.348)$ consumption was not associated with CVD mortality in the analysis of the highest $v$. the lowest consumption category. Similar associations were observed when the analysis was stratified by sex (Table 2).

The same two studies mentioned in the All-cause mortality section could not be included in the dose-response meta-analysis ${ }^{(16,30)}$. In the dose-response meta-analysis, the RR per $50 \mathrm{~g} / \mathrm{d}$ increase in processed meat intake (RR 1.24; $95 \%$ CI $\left.1.09,1.40 ; I^{2}=76.4 \%, P=0.001\right)$ and the RR per $100 \mathrm{~g} / \mathrm{d}$ increase in red meat intake (RR 1.15;95\% CI 1.05 , $\left.1.26 ; I^{2}=76.6 \%, P<0.001\right)$ were positively associated with CVD mortality. In the analysis stratified by sex, the association between red meat consumption and CVD mortality was strengthened in both sexes, while the association between processed meat consumption and CVD mortality was strengthened only in women (Table 2 ).

No associations were observed between total and white meat consumption and CVD mortality in the dose-response metaanalysis, and similar associations were observed in the analysis stratified by sex (Table 2 and Supplementary Figs. 4-5). There was no evidence of publication bias in any of the analyses.

IHD mortality. In the meta-analysis of the highest $v$. the lowest consumption category, processed meat consumption was found to be not associated with IHD mortality (RR 1.52; 


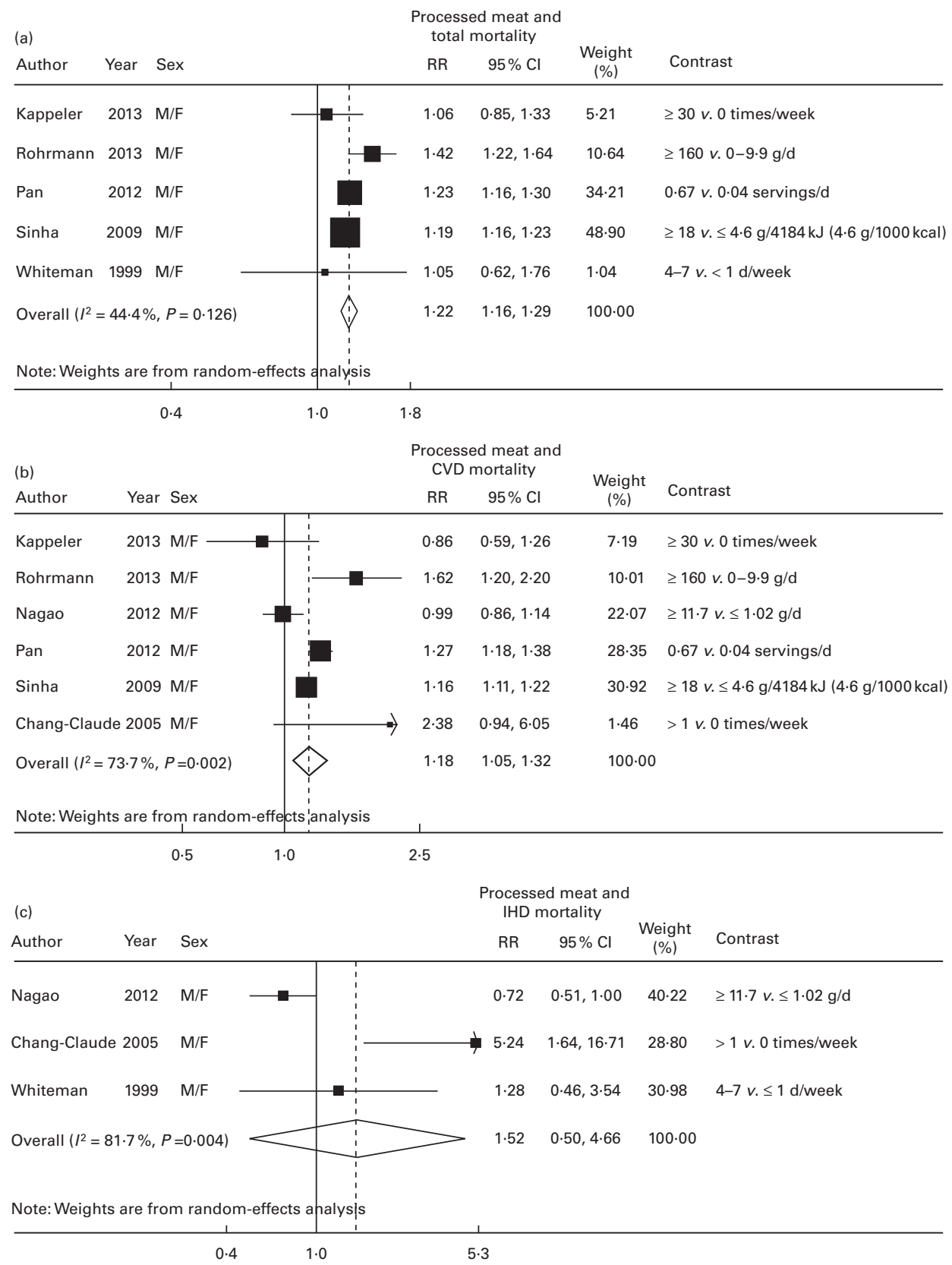

Fig. 2. Association between highest $v$. lowest processed meat consumption and (a) all-cause, (b) CVD and (c) IHD mortality risk. The relative risk (RR) of each study is represented by a and the size of the represents the weight of each study to the overall estimate. $95 \% \mathrm{Cl}$ are represented by — and the $\diamond$ represents the overall estimate and its $95 \% \mathrm{Cl}$.

$95 \%$ CI $\left.0 \cdot 50,4 \cdot 66 ; I^{2}=81 \cdot 7, P=0 \cdot 004\right)$, but the $95 \%$ CI was broad and shifted to the right (Fig. 2(c)). Red meat consumption was not associated with IHD mortality (RR 1.02; $95 \% \mathrm{CI}$ $0.72,1.46 ; I^{2}=70 \cdot 3, P=0 \cdot 018$ ) (Fig. 3(c)). Similarly, total meat (RR 1.52; 95\% CI $\left.0.68,3.40 ; I^{2}=82.7, P=0.030\right)$ and white meat (RR $1.00 ; 95 \%$ CI $0.82,1 \cdot 21 ; I^{2}=0, P=0 \cdot 780$ ) consumption was not associated with IHD mortality. Only the analysis of red meat consumption could be stratified by sex. No association was observed between red meat consumption and IHD mortality either in men (RR 1.30; $95 \%$ CI $0 \cdot 66,2 \cdot 55$; $\left.I^{2}=82 \cdot 5, P=0.003\right)$ or in women (RR $1 \cdot 17 ; 95 \%$ CI 0.89 , $\left.1 \cdot 53 ; I^{2}=0, P=0 \cdot 447\right)$
Similar associations were observed in the dose-response meta-analysis for all types of meats analysed (Table 2).

There was no evidence of publication bias determined by Begg's $(P>0 \cdot 10)$ and Egger's tests $(P>0 \cdot 10)$ in any of the analyses.

Subgroup analyses. Stratified analyses were carried out for red and processed meat consumption and total and CVD mortality risk to examine the sources of heterogeneity. Most results were consistent across the strata (Tables 3 and 4). Larger studies ( $\geq 5000$ cases) and studies with longer follow-up periods ( $\geq 20$ years) reported, on average, stronger associations of red and processed meat consumption 


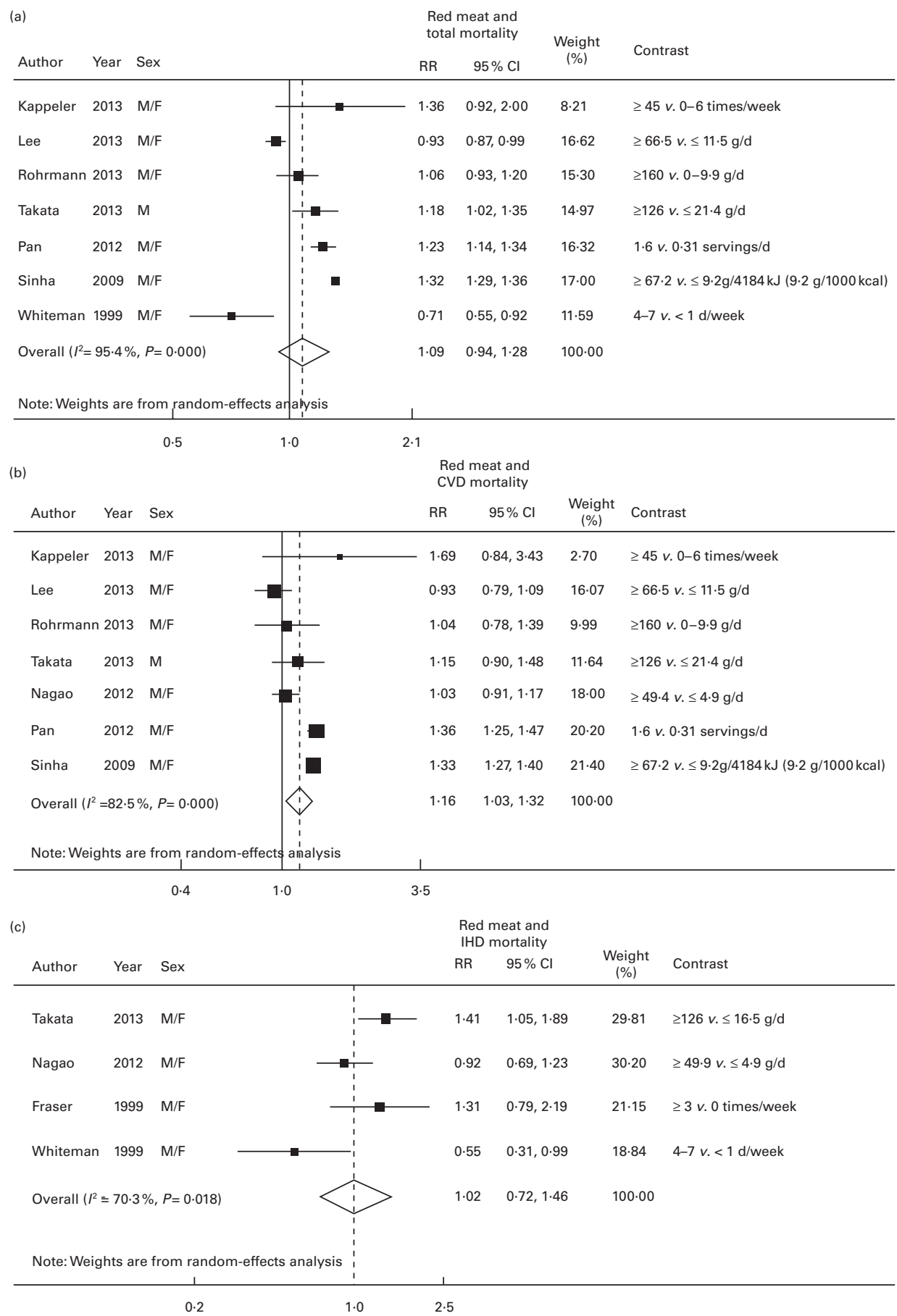

Fig. 3. Association between highest $v$. lowest red meat consumption and (a) all-cause, (b) CVD and (c) IHD mortality risk. The relative risk (RR) of each study is represented by a $\square$ and the size of the $\square$ represents the weight of each study to the overall estimate. $95 \% \mathrm{Cl}$ are represented by the - and the $\diamond$ represent the overall estimate and its $95 \% \mathrm{Cl}$.

with total and CVD mortality compared with the other studies. In general, studies that included adjustment variables such as total energy intake, fruits and vegetables, smoking history, physical activity, cardiovascular risk factors, vitamin supplements and BMI, on average, in the model reported stronger associations of red and processed meat consumption with total and CVD mortality, but this did not lead to a reduction of the heterogeneity. Studies that adjusted for socioeconomic status reported, on average, weaker associations of red and processed meat consumption with total and cardiovascular mortality compared with studies that did not adjust for it (Tables 3 and 4).

\section{Discussion}

In the present meta-analysis, processed meat consumption was found to be associated with an increased risk of mortality from any cause and CVD. Subjects in the highest 
Table 2. Summary of the estimated relative risks (RR) and $95 \%$ confidence intervals

\begin{tabular}{|c|c|c|c|c|c|c|c|c|c|c|c|c|c|c|c|}
\hline & \multicolumn{5}{|c|}{ All-cause mortality } & \multicolumn{5}{|c|}{ CVD mortality } & \multicolumn{5}{|c|}{ IHD mortality } \\
\hline & $n$ & $\mathrm{RR}$ & $95 \% \mathrm{Cl}$ & $I^{2}$ & $P_{\mathrm{h}}$ & $n$ & $\mathrm{RR}$ & $95 \% \mathrm{Cl}$ & $I^{2}$ & $P_{\mathrm{h}}$ & $n$ & $\mathrm{RR}$ & $95 \% \mathrm{Cl}$ & $I^{2}$ & $P_{\mathrm{h}}$ \\
\hline \multicolumn{16}{|c|}{ Dose-response* } \\
\hline \multicolumn{16}{|c|}{ All } \\
\hline TM & 3 & $1 \cdot 10$ & $0.94,1.30$ & $47 \cdot 2$ & 0.150 & 3 & $1 \cdot 12$ & $0.96,1.29$ & $68 \cdot 0$ & 0.044 & 3 & 1.38 & $0.39,4.87$ & $87 \cdot 3$ & $<0.001$ \\
\hline RM & 6 & 1.04 & $0.92,1.17$ & 95 & $<0.001$ & 6 & $1 \cdot 15$ & $1.05,1.26$ & $76 \cdot 6$ & $<0.001$ & 3 & 0.86 & $0.46,1.62$ & 77 & 0.013 \\
\hline WM & 5 & 0.90 & $0.73,1.11$ & $92 \cdot 1$ & $<0.001$ & 5 & 1.00 & $0.87,1.15$ & $36 \cdot 6$ & 0.177 & 3 & $1 \cdot 10$ & $0.63,1.89$ & 0 & 0.539 \\
\hline PM & 5 & 1.25 & $1.07,1.45$ & 95.7 & $<0.001$ & 6 & 1.24 & $1.09,1.40$ & $76 \cdot 4$ & 0.001 & 3 & $1 \cdot 14$ & $0.22,6.02$ & 63.4 & 0.065 \\
\hline \multicolumn{16}{|l|}{ Men } \\
\hline TM & 0 & $\mathrm{NC}$ & & & & 0 & NC & & & & 0 & NC & & & \\
\hline RM & 5 & 1.21 & $1 \cdot 15,1 \cdot 26$ & $47 \cdot 7$ & 0.137 & 5 & 1.20 & $1 \cdot 12,1 \cdot 30$ & 32.5 & 0.205 & 0 & NC & & & \\
\hline WM & 4 & 0.87 & $0.65,1 \cdot 17$ & 84.4 & $<0.001$ & 4 & 1.05 & $0.84,1.31$ & 27 & 0.250 & 0 & NC & & & \\
\hline PM & 4 & 1.23 & $1 \cdot 10,1.37$ & 86.0 & $<0.001$ & 4 & $1 \cdot 15$ & $0.96,1.37$ & 61.9 & 0.049 & 0 & NC & & & \\
\hline \multicolumn{16}{|c|}{ Women } \\
\hline TM & 0 & NC & & & & 0 & NC & & & & 0 & NC & & & \\
\hline RM & 5 & $1 \cdot 14$ & $1.00,1.30$ & 91.4 & $<0.001$ & 5 & 1.26 & $1.08,1.47$ & 75.5 & 0.003 & 0 & NC & & & \\
\hline WM & 4 & 1.01 & $0.89,1.15$ & $23 \cdot 6$ & 0.269 & 4 & 1.08 & $0.94,1.24$ & 0 & 0.630 & 0 & NC & & & \\
\hline PM & 4 & 1.34 & $1.09,1.66$ & 93.7 & $<0.001$ & 4 & 1.64 & $1 \cdot 25,2 \cdot 15$ & $72 \cdot 2$ & 0.013 & 0 & NC & & & \\
\hline \multirow{2}{*}{\multicolumn{16}{|c|}{ Highest $v$. lowest }} \\
\hline All & & & & & & & & & & & & & & & \\
\hline TM & 5 & 1.04 & $0.84,1.30$ & $86 \cdot 9$ & $<0.001$ & 5 & 1.08 & $0.85,1.36$ & $90 \cdot 6$ & $<0.001$ & 3 & 1.52 & $0.68,3.40$ & $82 \cdot 7$ & 0.030 \\
\hline $\mathrm{RM}$ & 7 & 1.09 & $0.94,1.28$ & 95.4 & $<0.001$ & 7 & $1 \cdot 16$ & $1.03,1.32$ & 82.5 & $<0.001$ & 4 & 1.02 & $0.72,1.46$ & $70 \cdot 3$ & 0.018 \\
\hline WM & 6 & 0.94 & $0.84,1.05$ & 88.2 & $<0.001$ & 6 & 1.01 & $0.96,1.07$ & $10 \cdot 6$ & 0.348 & 3 & 1.00 & $0.82,1.21$ & 0 & 0.780 \\
\hline PM & 5 & 1.22 & $1 \cdot 16,1.29$ & 44.4 & 0.126 & 6 & $1 \cdot 18$ & $1.05,1.32$ & 73.5 & 0.002 & 3 & 1.52 & $0.52,4.66$ & $81 \cdot 7$ & 0.004 \\
\hline \multicolumn{16}{|l|}{ Men } \\
\hline TM & 0 & NC & & & & 3 & 1.08 & $0.84,1.39$ & 88.4 & $<0.001$ & 0 & NC & & & \\
\hline RM & 6 & $1 \cdot 17$ & $1.04,1.32$ & $89 \cdot 3$ & $<0.001$ & 6 & $1 \cdot 10$ & $0.92,1.30$ & 88 & $<0.001$ & 3 & 1.30 & $0.66,2.55$ & 82.5 & 0.003 \\
\hline WM & 5 & 0.94 & $0.81,1.08$ & 88.5 & $<0.001$ & 5 & 0.95 & $0.85,1.07$ & $46 \cdot 5$ & 0.113 & 0 & NC & & & \\
\hline PM & 4 & 1.22 & $1.13,1.31$ & 60.9 & 0.053 & 4 & $1 \cdot 10$ & $0.98,1.24$ & 58.6 & 0.064 & 0 & NC & & & \\
\hline \multicolumn{16}{|c|}{ Women } \\
\hline TM & 0 & NC & & & & 3 & $1 \cdot 17$ & $0.92,1.49$ & 88.4 & $<0.001$ & 0 & NC & & & \\
\hline RM & 5 & $1 \cdot 13$ & $0.96,1.34$ & $94 \cdot 1$ & $<0.001$ & 5 & 1.29 & $1.09,1.54$ & $82 \cdot 4$ & $<0.001$ & 3 & $1 \cdot 17$ & $0.89,1.53$ & 0 & 0.447 \\
\hline WM & 4 & 0.95 & $0.91,0.99$ & 0 & 0.805 & 4 & 1.05 & $0.97,1.14$ & 0 & 0.911 & 0 & NC & & & \\
\hline PM & 4 & 1.23 & $1 \cdot 19,1 \cdot 27$ & 0 & 0.670 & 4 & 1.21 & $1.05,1.40$ & 71.7 & 0.014 & 0 & NC & & & \\
\hline
\end{tabular}

$P_{\mathrm{h}}$, heterogeneity $P$ value; TM, total meat; RM, red meat; WM, white meat; PM, processed meat; NC, not calculable.

* 
Table 3. Results of the subgroup analyses (for the highest $v$. the lowest consumption) of studies evaluating red meat consumption and all-cause and CVD mortality as clinical outcomes

(Relative risks (RR) and 95\% confidence intervals)

\begin{tabular}{|c|c|c|c|c|c|c|c|c|c|c|}
\hline \multirow{2}{*}{$\begin{array}{l}\text { Red meat } \\
\text { Study characteristics }\end{array}$} & \multicolumn{5}{|c|}{ Total mortality } & \multicolumn{5}{|c|}{ CVD mortality } \\
\hline & $n$ & $\mathrm{RR}$ & $95 \% \mathrm{Cl}$ & $I^{2}(\%)$ & $P_{\mathrm{h}}$ & $n$ & $\mathrm{RR}$ & $95 \% \mathrm{Cl}$ & $I^{2}(\%)$ & $P_{\mathrm{h}}$ \\
\hline All studies & 7 & 1.09 & $0.94,1.28$ & $95 \cdot 4$ & $<0.001$ & 7 & $1 \cdot 16$ & $1.03,1.32$ & $82 \cdot 5$ & $<0.001$ \\
\hline \multicolumn{11}{|l|}{ Follow-up } \\
\hline$<20$ years & 5 & 1.04 & $0.84,1.27$ & $97 \cdot 0$ & $<0.001$ & 5 & $1 \cdot 10$ & $0.92,1.31$ & $86 \cdot 8$ & $<0.001$ \\
\hline$\geq 20$ years & 2 & 1.24 & $1.14,1.34$ & 0 & 0.620 & 2 & 1.36 & $1.26,1.48$ & 0 & 0.548 \\
\hline \multicolumn{11}{|l|}{ Cases } \\
\hline$<5000$ & 2 & 0.97 & $0.51,1.83$ & $86 \cdot 6$ & 0.006 & 3 & 1.08 & $0.94,1.23$ & $12 \cdot 8$ & 0.318 \\
\hline$\geq 5000$ & 5 & $1 \cdot 14$ & $0.96,1.34$ & 96.5 & $<0.001$ & 4 & $1 \cdot 19$ & $1.03,1.37$ & $85 \cdot 7$ & $<0.001$ \\
\hline \multicolumn{11}{|l|}{ Dietary intake assessment } \\
\hline Baseline only & 6 & 1.07 & $0.88,1.29$ & $96 \cdot 2$ & $<0.001$ & 6 & $1 \cdot 12$ & $0.94,1.32$ & 83.9 & $<0.001$ \\
\hline Updated & 1 & 1.23 & $1 \cdot 13,1.33$ & NC & NC & 1 & 1.36 & $1.25,1.47$ & NC & NC \\
\hline Validated & 5 & $1 \cdot 14$ & $0.96,1.34$ & $96 \cdot 5$ & $<0.001$ & 6 & 1.15 & $1.01,1.31$ & $85 \cdot 2$ & $<0.001$ \\
\hline Not validated & 2 & 0.97 & $0.51,1.83$ & $86 \cdot 6$ & 0.006 & 1 & 1.69 & $0.84,3.42$ & $\mathrm{NC}$ & NC \\
\hline \multicolumn{11}{|l|}{ Consumption categories } \\
\hline Predefined & 3 & 0.99 & $0.72,1.36$ & 80 & 0.007 & 2 & $1 \cdot 19$ & $0.78,1.81$ & $36 \cdot 1$ & 0.211 \\
\hline Not predefined (quintiles) & 4 & $1 \cdot 16$ & $0.96,1.40$ & $97 \cdot 2$ & $<0.001$ & 5 & $1 \cdot 16$ & $1.02,1.33$ & $87 \cdot 4$ & $<0.001$ \\
\hline \multicolumn{11}{|l|}{ Adjustment variables } \\
\hline \multicolumn{11}{|l|}{ Socio-economic status } \\
\hline Yes & 3 & 1.03 & $0.72,1.49$ & 84.7 & 0.001 & 2 & $1 \cdot 20$ & $0.94,1.54$ & $2 \cdot 2$ & 0.312 \\
\hline No & 4 & $1 \cdot 13$ & $0.93,1.36$ & $97 \cdot 3$ & $<0.001$ & 5 & $1 \cdot 15$ & $1.00,1.32$ & 87.9 & $<0.001$ \\
\hline \multicolumn{11}{|l|}{ Education level } \\
\hline Yes & 4 & $1 \cdot 11$ & $0.90,1.38$ & $97 \cdot 3$ & $<0.001$ & 5 & $1 \cdot 10$ & $0.92,1.31$ & $86 \cdot 8$ & $<0.001$ \\
\hline No & 3 & 1.05 & $0.72,1.54$ & 87.9 & $<0.001$ & 2 & 1.36 & $1.26,1.48$ & 0 & 0.548 \\
\hline \multicolumn{11}{|l|}{ Total energy } \\
\hline Yes & 5 & $1 \cdot 14$ & $0.96,1.34$ & $96 \cdot 5$ & $<0.001$ & 6 & $1 \cdot 15$ & $1.01,1.31$ & $85 \cdot 2$ & $<0.001$ \\
\hline No & 2 & 0.97 & $0.51,1.83$ & $86 \cdot 6$ & 0.006 & 1 & 1.69 & $0.84,3.42$ & $\mathrm{NC}$ & NC \\
\hline \multicolumn{11}{|l|}{ Fruits and vegetables } \\
\hline Yes & 6 & $1 \cdot 10$ & $0.92,1.31$ & 96 & $<0.001$ & 6 & $1 \cdot 18$ & $1.03,1.34$ & 84.6 & $<0.001$ \\
\hline No & 1 & 1.06 & $0.93,1.20$ & $\mathrm{NC}$ & $\mathrm{NC}$ & 1 & 1.04 & $0.78,1.39$ & $\mathrm{NC}$ & NC \\
\hline \multicolumn{11}{|l|}{ Other foods } \\
\hline Yes & 4 & 1.06 & $0.90,1.25$ & 83.2 & $<0.001$ & 4 & $1 \cdot 15$ & $0.97,1.38$ & $80 \cdot 2$ & 0.002 \\
\hline No & 3 & $1 \cdot 16$ & $0.86,1.57$ & $98 \cdot 1$ & $<0.001$ & 3 & 1.19 & $0.87,1.62$ & 88.9 & $<0.001$ \\
\hline \multicolumn{11}{|l|}{ Smoking history } \\
\hline Yes & 3 & 1.20 & $1.03,1.38$ & $85 \cdot 1$ & 0.001 & 3 & 1.23 & $1.06,1.43$ & $48 \cdot 2$ & 0.145 \\
\hline \multirow{2}{*}{\multicolumn{11}{|c|}{ Physical activity }} \\
\hline & & & & & & & & & & \\
\hline Yes & 5 & 1.22 & $0.81,1.27$ & $74 \cdot 2$ & 0.004 & 6 & $1 \cdot 22$ & $1 \cdot 10,1 \cdot 36$ & $73 \cdot 6$ & 0.002 \\
\hline No & 2 & 0.84 & $0.65,1.08$ & 75 & 0.046 & 1 & 0.93 & $0.79,1.09$ & $\mathrm{NC}$ & NC \\
\hline \multicolumn{11}{|l|}{ CVD risk factors } \\
\hline Yes & 3 & 1.22 & $1 \cdot 14,1 \cdot 31$ & 0 & 0.757 & 4 & $1 \cdot 21$ & $0.99,1.47$ & $79 \cdot 2$ & 0.002 \\
\hline No & 4 & 1.00 & $0.78,1.28$ & $97 \cdot 7$ & $<0.001$ & 3 & $1 \cdot 10$ & $0.84,1.44$ & $89 \cdot 7$ & $<0.001$ \\
\hline \multicolumn{11}{|l|}{ Vitamin supplements } \\
\hline Yes & 3 & $1 \cdot 30$ & $1.23,1.37$ & $31 \cdot 6$ & 0.232 & 3 & $1 \cdot 34$ & $1 \cdot 28,1.40$ & 0 & 0.728 \\
\hline No & 4 & 0.98 & $0.84,1.14$ & $82 \cdot 1$ & $<0.001$ & 4 & 1.01 & $0.93,1.11$ & 0 & 0.536 \\
\hline \multicolumn{11}{|l|}{$\mathrm{BMI}$} \\
\hline Yes & 5 & $1 \cdot 15$ & $0.96,1.38$ & $96 \cdot 4$ & $<0.001$ & 5 & $1 \cdot 15$ & $1.00,1.32$ & 87.9 & $<0.001$ \\
\hline No & 2 & 0.93 & $0.56,1.52$ & $91 \cdot 3$ & 0.001 & 2 & 1.20 & $0.94,1.54$ & $2 \cdot 2$ & 0.312 \\
\hline
\end{tabular}

$P_{\mathrm{h}}$, heterogeneity $P$ value; NC, not calculable.

category of processed meat consumption had 22 and 18\% higher mortality risk from any cause and CVD, respectively, than those in the lowest category of consumption. On the other hand, red meat consumption was associated only with an increased risk of CVD mortality. In the analysis stratified by sex, the association of processed and red meat consumption with CVD mortality remained significant in women but not in men. It is unclear whether these differences in the association are due to physiological differences between the sexes or simply due to differences in the selected studies. Only one study reported sex differences in the association between red meat consumption and IHD mortality, showing a significant association in men but not in women ${ }^{(18)}$

Overall, the results of this meta-analysis indicate that the consumption of both red meat and processed meat might have an adverse effect on health, increasing the risk of CVD mortality. When all types of meats were considered together, no association was found to emerge, which highlights the importance of considering each type of meat separately. These findings are in agreement with those of a very recent meta-analysis on the relationship between red and processed meat consumption and all-cause mortality, in which subjects in the highest category of processed and total red meat 
Table 4. Results of the subgroup analyses (for the highest $v$. the lowest consumption) of studies evaluating processed meat consumption and allcause and CVD mortality as clinical outcomes

(Relative risks (RR) and 95\% confidence intervals)

\begin{tabular}{|c|c|c|c|c|c|c|c|c|c|c|}
\hline \multirow{2}{*}{$\begin{array}{l}\text { Processed meat } \\
\text { Study characteristics }\end{array}$} & \multicolumn{5}{|c|}{ Total mortality } & \multicolumn{5}{|c|}{ CVD mortality } \\
\hline & $n$ & $\mathrm{RR}$ & $95 \% \mathrm{Cl}$ & $I^{2}(\%)$ & $P_{\mathrm{h}}$ & $n$ & $\mathrm{RR}$ & $95 \% \mathrm{Cl}$ & $I^{2}(\%)$ & $P_{\mathrm{h}}$ \\
\hline All studies & 5 & $1 \cdot 22$ & $1 \cdot 16,1 \cdot 29$ & 44.4 & 0.126 & 6 & $1 \cdot 18$ & $1.05,1.32$ & $73 \cdot 7$ & 0.002 \\
\hline \multicolumn{11}{|l|}{ Follow-up } \\
\hline$<20$ years & 3 & $1 \cdot 26$ & $1.09,1.45$ & $67 \cdot 2$ & 0.069 & 3 & $1 \cdot 17$ & $0.98,1.39$ & $78 \cdot 9$ & 0.009 \\
\hline$\geq 20$ years & 2 & $1 \cdot 19$ & $1.05,1.34$ & $37 \cdot 2$ & 0.207 & 3 & $1 \cdot 20$ & $0.83,1.72$ & 65 & 0.057 \\
\hline \multicolumn{11}{|l|}{ Cases } \\
\hline$<5000$ & 2 & 1.06 & $0.86,1.30$ & 0 & 0.974 & 3 & 1.02 & $0.76,1.38$ & $49 \cdot 2$ & 0.140 \\
\hline$\geq 5000$ & 3 & $1 \cdot 23$ & $1 \cdot 16,1 \cdot 31$ & $64 \cdot 8$ & 0.058 & 3 & $1 \cdot 25$ & $1 \cdot 12,1 \cdot 39$ & $74 \cdot 1$ & 0.021 \\
\hline \multicolumn{11}{|l|}{ Dietary intake assessment } \\
\hline Baseline only & 4 & $1 \cdot 22$ & $1 \cdot 09,1 \cdot 37$ & 54 & 0.089 & 4 & $1 \cdot 12$ & $0.95,1.33$ & $74 \cdot 3$ & 0.009 \\
\hline Updated & 1 & $1 \cdot 23$ & $1 \cdot 16,1 \cdot 30$ & $\mathrm{NC}$ & NC & 2 & 1.45 & $0.88,2.41$ & $42 \cdot 4$ & 0.188 \\
\hline Validated & 3 & $1 \cdot 23$ & $1 \cdot 16,1 \cdot 31$ & $64 \cdot 8$ & 0.058 & 4 & $1 \cdot 19$ & $1.06,1.33$ & $78 \cdot 8$ & 0.003 \\
\hline Not validated & 2 & 1.06 & $0.86,1.30$ & 0 & 0.974 & 2 & $1 \cdot 30$ & $0.49,3.48$ & 74.6 & 0.047 \\
\hline \multicolumn{11}{|l|}{ Consumption categories } \\
\hline Predefined & 3 & $1 \cdot 21$ & $0.96,1.54$ & $61 \cdot 3$ & 0.075 & 3 & $1 \cdot 37$ & $0.80,2 \cdot 35$ & $75 \cdot 6$ & 0.017 \\
\hline Not predefined (quintiles) & 2 & $1 \cdot 20$ & $1 \cdot 17,1 \cdot 23$ & 0 & 0.355 & 3 & $1 \cdot 15$ & $1 \cdot 04,1 \cdot 28$ & 79.5 & 0.007 \\
\hline \multicolumn{11}{|l|}{ Adjustment variables } \\
\hline \multicolumn{11}{|l|}{ Socio-economic status } \\
\hline Yes & 2 & 1.06 & $0.86,1.30$ & 0 & 0.974 & 1 & 0.86 & $0.59,1.26$ & $\mathrm{NC}$ & NC \\
\hline No & 3 & $1 \cdot 23$ & $1 \cdot 16,1 \cdot 31$ & $64 \cdot 8$ & 0.058 & 5 & $1 \cdot 20$ & $1.07,1.35$ & $75 \cdot 5$ & 0.003 \\
\hline \multicolumn{11}{|l|}{ Education level } \\
\hline Yes & 2 & $1 \cdot 28$ & $1.08,1.51$ & $80 \cdot 4$ & 0.024 & 4 & $1 \cdot 20$ & $1.00,1.45$ & $74 \cdot 6$ & 0.008 \\
\hline No & 3 & $1 \cdot 22$ & $1 \cdot 15,1 \cdot 29$ & 0 & 0.386 & 2 & 1.09 & $0.75,1.59$ & $74 \cdot 3$ & 0.049 \\
\hline \multicolumn{11}{|l|}{ Total energy } \\
\hline Yes & 3 & $1 \cdot 23$ & $1 \cdot 16,1 \cdot 31$ & $64 \cdot 8$ & 0.058 & 4 & $1 \cdot 19$ & $1 \cdot 06,1.33$ & $78 \cdot 8$ & 0.003 \\
\hline No & 2 & 1.06 & $0.86,1.30$ & 0 & 0.974 & 2 & $1 \cdot 30$ & $0.49,3.48$ & $74 \cdot 6$ & 0.047 \\
\hline \multicolumn{11}{|l|}{ Fruits and vegetables } \\
\hline Yes & 4 & $1 \cdot 20$ & $1 \cdot 17,1.23$ & 0 & 0.517 & 4 & $1 \cdot 13$ & $1.01,1.26$ & $75 \cdot 8$ & 0.006 \\
\hline No & 1 & 1.42 & $1.22,1.65$ & $\mathrm{NC}$ & $\mathrm{NC}$ & 2 & 1.68 & $1 \cdot 26,2 \cdot 24$ & 0 & 0.441 \\
\hline \multicolumn{11}{|l|}{ Other foods } \\
\hline Yes & 3 & $1 \cdot 28$ & $1 \cdot 14,1.44$ & $44 \cdot 3$ & 0.166 & 3 & $1 \cdot 23$ & $0.99,1.53$ & $84 \cdot 6$ & 0.002 \\
\hline No & 2 & $1 \cdot 19$ & $1 \cdot 13,1 \cdot 25$ & $6 \cdot 6$ & 0.301 & 3 & $1 \cdot 13$ & $0.82,1.55$ & $57 \cdot 1$ & 0.097 \\
\hline \multicolumn{11}{|l|}{ Smoking history } \\
\hline Yes & 2 & $1 \cdot 28$ & $1.08,1.51$ & $80 \cdot 4$ & 0.024 & 2 & $1 \cdot 32$ & $0.96,1.82$ & 78 & 0.033 \\
\hline No & 3 & $1 \cdot 22$ & $1 \cdot 15,1.29$ & 0 & 0.386 & 4 & $1 \cdot 11$ & $0.89,1.40$ & 79 & 0.003 \\
\hline \multicolumn{11}{|l|}{ Physical activity } \\
\hline Yes & 4 & $1 \cdot 22$ & $1 \cdot 15,1 \cdot 30$ & $56 \cdot 7$ & 0.074 & 6 & $1 \cdot 18$ & $1.05,1.32$ & $73 \cdot 7$ & 0.002 \\
\hline No & 1 & 1.05 & $0.62,1.77$ & $\mathrm{NC}$ & NC & 0 & - & & - & - \\
\hline \multicolumn{11}{|l|}{ Vitamin supplements } \\
\hline Yes & 3 & $1 \cdot 20$ & $1 \cdot 17,1 \cdot 23$ & 1.4 & 0.363 & 3 & $1 \cdot 18$ & $1 \cdot 07,1.31$ & $69 \cdot 4$ & 0.038 \\
\hline No & 2 & $1 \cdot 36$ & $1.11,1.67$ & 16 & 0.275 & 3 & $1 \cdot 38$ & $0.87,2.19$ & 82 & 0.004 \\
\hline \multicolumn{11}{|l|}{ CVD risk factors } \\
\hline Yes & 2 & $1 \cdot 19$ & $1.05,1.34$ & $37 \cdot 2$ & 0.207 & 2 & 1.09 & $0.75,1.59$ & $74 \cdot 3$ & 0.049 \\
\hline No & 3 & $1 \cdot 26$ & $1.09,1.45$ & $62 \cdot 7$ & 0.069 & 4 & $1 \cdot 20$ & $1.00,1.45$ & 74.6 & 0.008 \\
\hline \multicolumn{11}{|l|}{ BMI } \\
\hline Yes & 3 & $1 \cdot 23$ & $1 \cdot 16,1 \cdot 31$ & $64 \cdot 8$ & 0.058 & 6 & $1 \cdot 18$ & $1.05,1.32$ & 73.7 & 0.002 \\
\hline No & 2 & 1.06 & $0.86,1.30$ & 0 & 0.974 & 0 & - & - & - & - \\
\hline
\end{tabular}

$P_{\mathrm{h}}$, heterogeneity $P$ value; NC not calculable.

consumption were found to have an increased all-cause mortality risk of 23 and $29 \%$, respectively, compared with those in the lowest consumption category. Previous meta-analyses on the association between red and processed meat consumption and CVD incidence, type 2 diabetes and certain types of cancers, such as colorectal cancer, have also found positive associations $^{(6-10)}$. It has been suggested that the consumption of red meat, especially processed meat, may increase the risk of all-cause mortality as well as CVD mortality by means of several components that boost cardiovascular alterations. Saturated fat, cholesterol and haeme Fe contents in meats seem to be the key factors involved in atherosclerotic processes that promote the appearance of cardiovascular risk factors and chronic diseases such as hypertension, hypercholesterolaemia, endothelial dysfunction, insulin resistance and type 2 diabetes ${ }^{(35,36)}$. On the other hand, preservatives such as $\mathrm{Na}$ and nitrates in processed meats might explain the positive associations observed for processed meat but not for red meat ${ }^{(9)}$. High Na consumption is a well-recognised factor for the development of hypertension; nitrates and their derivatives have been reported to be associated with oxidative stress processes promoting metabolic disturbances in main organs and tissues, resulting in insulin resistance, endothelial dysfunction, type 2 diabetes and some types of cancers ${ }^{(6,37)}$. Inflammatory mechanisms have also been proposed as intermediary processes promoting atherosclerosis, CVD and type 
2 diabetes. In a recent cross-sectional study conducted in the Nurses' Health Study, increased C-reactive protein levels have been observed in women consuming higher quantities of red and processed meat than in those consuming lower quantities ${ }^{(38)}$.

The association between red meat consumption and CVD mortality became stronger when the Asian studies $(15,16,18)$ were excluded from the analysis. Meat consumption in Asian countries is considerably lower than that in Western countries $^{(16)}$, which could explain in part the weak associations observed in the cohort studies. In a pooled analysis of eight Asian cohorts, the association between red meat consumption and CVD mortality was found to be inverse and statistically significant ${ }^{(16)}$. The authors indicated that dietary factors, lifestyle, socio-economic status and disease distribution are changing in Asian countries and, thus, other factors may be stronger predictors of mortality than meat consumption. On the other hand, the food preparation technique, which is not considered in observational prospective cohort studies, might also have a role.

Very little has been reported on the effect of white meat consumption on mortality risk. In the analysis of the highest $v$. the lowest consumption category, a weak inverse association was observed in women for all-cause mortality. Previously, Sinha et al. ${ }^{(11)}$ had observed a small decrease in total and cancer mortality risk in men and women consuming higher quantities of white meat. Recently, Lee et $a l{ }^{(16)}$ have also found an inverse association between poultry intake and total mortality in men and women. However, the interpretation of the effect of white meat consumption on health is a difficult task, as subjects consuming more white meat are, at the same time, consuming less red meat. Findings obtained in the present meta-analysis are weak and not conclusive. More studies assessing the effect of white meat consumption on mortality are required.

The present meta-analysis has several strengths. The large number of total and CVD mortality cases provided the statistical power to detect meaningful associations with the exposure. We summarised the RR estimates for the highest $v$. the lowest level of intake in the studies and used generalised least-squares models for trend estimation and dose-response assessments. The analyses were conducted by types of meats (total, red, white and processed), and only two studies classified red meat ${ }^{(11)}$ and processed meat ${ }^{(28)}$ differently. An analysis excluding these studies was also carried and the association was found to not change (data not shown). On the other hand, although in almost all analyses there was no evidence of publication bias determined by Begg's and Egger's tests, such tests have limited statistical power in the setting of relatively few studies. We contacted authors and included unpublished results to reduce the potential impact of publication bias.

The limitations of the meta-analysis should also be mentioned. Long-term prospective cohorts are limited by misclassification and residual confounding ${ }^{(39)}$; thus, each of these studies has potential limitations, and our findings should be interpreted in that context. It is possible that the observed positive association between red and processed meat consumption and all-cause and CVD mortality could be due to unmeasured or residual confounding. Most of the studies used models adjusted for several factors; however, residual confounding could still be present as a result of imperfect covariate measurement. Measurement of dietary intake data is imperfect, and measurement error would likely lead to an underestimation of the true effect of the exposures with the outcome. Only two studies updated dietary intake data during follow-up or corrected their estimates for the effect of measurement error ${ }^{(12,19)}$. Similarly, higher consumption of processed meat is often associated with other unhealthy lifestyles including physical inactivity, overweight, smoking, and low fruit and vegetable intake. Although several studies included some food groups as adjustment variables, none of the studies adjusted by dietary patterns, leading to possible residual confounding by an overall dietary pattern.

Socio-economic status could be an important confounder. Studies that did not adjust for socio-economic status tended to show stronger RR. Finally, heterogeneity was apparent in many of the models, which could be partly explained by differences between the studies with regard to the amount of meat consumed (mean or median from the highest and lowest categories) and the type of meat items considered in each meat group and the duration of follow-up, as well as the method used for dietary intake assessment.

Because of the possibility of residual confounding and there is significant heterogeneity in many of the models, the summary risk estimates should be interpreted with caution.

In conclusion, we found that processed meat consumption could increase the risk of any-cause and CVD mortality, while red meat consumption is only positively but weakly associated with CVD mortality. These findings highlight the importance of differentiating the meat types as the impact of processed meat consumption seems to be stronger than that of unprocessed meat consumption, but policy efforts should focus on limiting red meat and processed meat intake. More studies assessing the impact of meat consumption on IHD mortality are required. On the other hand, white meat consumption might be the 'healthy' alternative to red and processed meat consumption; however, more studies assessing the specific role of white meat consumption in CVD are essential.

Overall, the results of this meta-analysis should be interpreted with caution due to the high heterogeneity obtained in most of the analyses as well as the possibility of residual confounding.

\section{Supplementary material}

To view supplementary material for this article, please visit http://dx.doi.org/10.1017/S000711451400124X

\section{Acknowledgements}

The authors thank Nagao Masanori and Sabine Rohrmann for providing supplementary data from the Japan Collaborative Cohort Study and the Third National Health and Nutrition Examination Survey. 
This research received no specific grant from any funding agency or commercial or not-for-profit sectors. I. A. G. received financial support from the Carlos III Health Institute of the Spanish Ministry of Health for her 'Sara Borrell' postdoctoral fellowship (CD11/00196). The Carlos III Health Institute had no role in the design and analysis of the research or in the writing of this article.

The authors' contributions are as follows: I. A. G., D. R. and T. N. were responsible for the study design; I. A. G. and A. R. V. were responsible for literature search, study selection, data extraction, and table and figure preparation; I. A. G. and A. R. V. analysed the data; I. A. G. wrote the manuscript; A. L. d. M. critically revised the manuscript. All authors contributed to the interpretation of the results, critically reviewed the manuscript for important intellectual content and approved the final version of the manuscript.

None of the authors has any conflicts of interest to declare.

\section{References}

1. Roger VL, Go AS, Lloyd-Jones DM, et al. (2012) Executive summary: heart disease and stroke statistics - 2012 update: a report from the American Heart Association. Circulation 125, 188-197.

2. Sacks FM \& Campos H (2010) Dietary therapy in hypertension. $N$ Engl J Med 362, 2102-2112.

3. Koeth RA, Wang Z, Levison BS, et al. (2013) Intestinal microbiota metabolism of L-carnitine, a nutrient in red meat, promotes atherosclerosis. Nat Med 19, 576-585.

4. Feskens EJ, Sluik D \& van Woudenbergh GJ (2013) Meat consumption, diabetes, and its complications. Curr Diab Rep 13, 298-306.

5. Cocate PG, Natali AJ, Oliveira AD, et al. (2013) Red but not white meat consumption is associated with metabolic syndrome, insulin resistance and lipid peroxidation in Brazilian middle-aged men. Eur J Prev Cardiol (epublication ahead of print version 8 October 2013).

6. Aune D, Ursin G \& Veierød MB (2009) Meat consumption and the risk of type 2 diabetes: a systematic review and meta-analysis of cohort studies. Diabetologia 52, 2277-2287.

7. Micha R, Wallace SK \& Mozaffarian D (2010) Red and processed meat consumption and risk of incident coronary heart disease, stroke, and diabetes mellitus: a systematic review and meta-analysis. Circulation 121, 2271-2283.

8. Micha R, Michas G \& Mozaffarian D (2012) Unprocessed red and processed meats and risk of coronary artery disease and type 2 diabetes - an updated review of the evidence. Curr Atheroscler Rep 14, 515-524.

9. Micha R, Michas G, Lajous M, et al. (2013) Processing of meats and cardiovascular risk: time to focus on preservatives. BMC Med 11, 136.

10. Chan DS, Lau R, Aune D, et al. (2011) Red and processed meat and colorectal cancer incidence: meta-analysis of prospective studies. PLOS ONE 6, e20456.

11. Sinha R, Cross AJ, Graubard BI, et al. (2009) Meat intake and mortality: a prospective study of over half a million people. Arch Intern Med 169, 562-571.

12. Pan A, Sun Q, Bernstein AM, et al. (2012) Red meat consumption and mortality: results from 2 prospective cohort studies. Arch Intern Med 172, 555-563.

13. Rohrmann S, Overvad K, Bueno-de-Mesquita HB, et al. (2013) Meat consumption and mortality - results from the European Prospective Investigation into Cancer and Nutrition. BMC Med 11, 63
14. Larsson SC \& Orsini N (2014) Red meat and processed meat consumption and all-cause mortality: a meta-analysis. $A m \mathrm{~J}$ Epidemiol 179, 282-289.

15. Nagao M, Iso H, Yamagishi K, et al. (2012) Meat consumption in relation to mortality from cardiovascular disease among Japanese men and women. Eur J Clin Nutr 66, 687-693.

16. Lee JE, McLerran DF, Rolland B, et al. (2013) Meat intake and cause-specific mortality: a pooled analysis of Asian prospective cohort studies. Am J Clin Nutr 98, 1032-1041.

17. Kappeler R, Eichholzer M \& Rohrmann S (2013) Meat consumption and diet quality and mortality in NHANES III. Eur J Clin Nutr 67, 598-606.

18. Takata Y, Shu XO, Gao YT, et al. (2013) Red meat and poultry intakes and risk of total and cause-specific mortality: results from cohort studies of Chinese adults in Shanghai. PLOS ONE 8, e 56963.

19. Chang-Claude J, Hermann S, Eilber U, et al. (2005) Lifestyle determinants and mortality in German vegetarians and health-conscious persons: results of a 21-year follow-up. Cancer Epidemiol Biomarkers Prev 14, 963-968.

20. Fraser GE \& Shavlik DJ (1997) Risk factors for all-cause and coronary heart disease mortality in the oldest-old. The Adventist Health Study. Arch Intern Med 157, 2249-2258.

21. Key TJ, Fraser GE, Thorogood M, et al. (1999) Mortality in vegetarians and nonvegetarians: detailed findings from a collaborative analysis of 5 prospective studies. Am J Clin Nutr 70, 516S-524S

22. Crowe FL, Appleby PN, Travis RC, et al. (2013) Risk of hospitalization or death from ischemic heart disease among British vegetarians and nonvegetarians: results from the EPIC-Oxford cohort study. Am J Clin Nutr 97, 597-603.

23. Fraser GE (1999) Associations between diet and cancer, ischemic heart disease, and all-cause mortality in nonHispanic white California Seventh-day Adventists. Am J Clin Nutr 70, 532-538.

24. Mann JI, Appleby PN, Key TJ, et al. (1997) Dietary determinants of ischaemic heart disease in health conscious individuals. Heart 78, 450-455.

25. DerSimonian R \& Laird N (1986) Meta-analysis in clinical trials. Control Clin Trials 7, 177-188

26. Greenland S \& Longnecker MP (1992) Methods for trend estimation from summarized dose-response data, with applications to meta-analysis. Am J Epidemiol 135, 1301-1309.

27. Orsini N, Bellocco R \& Greenland S (2006) Generalized least squares for trend estimation of summarized dose-response data. Stata J 6, 40-57.

28. Whiteman D, Muir J, Jones L, et al. (1999) Dietary questions as determinants of mortality: the OXCHECK experience. Public Health Nutr 2, 477-487.

29. Fortes C, Forastiere F, Farchi S, et al. (2000) Diet and overall survival in a cohort of very elderly people. Epidemiology $\mathbf{1 1}$, 440-445.

30. Jamrozik K, Broadhurst RJ, Forbes S, et al. (2000) Predictors of death and vascular events in the elderly: the Perth Community Stroke Study. Stroke 31, 863-868.

31. Norat T, Lukanova A, Ferrari P, et al. (2002) Meat consumption and colorectal cancer risk: dose-response meta-analysis of epidemiological studies. Int J Cancer 98, 241-256.

32. Higgins JP \& Thompson SG (2002) Quantifying heterogeneity in a meta-analysis. Stat Med 21, 1539-1558.

33. Egger M, Davey Smith G, Schneider M, et al. (1997) Bias in meta-analysis detected by a simple, graphical test. BMJ 315, 629-634. 
34. Begg CB \& Mazumdar M (1994) Operating characteristics of a rank correlation test for publication bias. Biometrics 50, 1088-1101.

35. Zhao Z, Li S, Liu G, et al. (2012) Body iron stores and hemeiron intake in relation to risk of type 2 diabetes: a systematic review and meta-analysis. PLOS ONE 7, e41641.

36. InterAct Consortium (2013) Association between dietary meat consumption and incident type 2 diabetes: the EPICInterAct study. Diabetologia 56, 47-59.

37. Aune D, Chan DS, Vieira AR, et al. (2013) Red and processed meat intake and risk of colorectal adenomas: a systematic review and meta-analysis of epidemiological studies. Cancer Causes Control 24, 611-627.

38. Ley SH, Sun Q, Willett WC, et al. (2014) Associations between red meat intake and biomarkers of inflammation and glucose metabolism in women. Am J Clin Nutr 99, 352-360.

39. Alexander DD (2013) No association between meat intake and mortality in Asian countries. Am J Clin Nutr 98, 865-866.

40. Moher D, Liberati A, Tetzlaff J, et al. (2009) Preferred reporting items for systematic reviews and meta-analyses: the PRISMA statement. PLoS Med 6, e1000097. 